\title{
PENGELOLAAN PROGRAM ULANGAN HARIAN BERSAMA (UHB) SEBAGAI UPAYA MENINGKATKAN MOTIVASI BELAJAR SISWA
}

\section{MANAGEMENT OF DAILY JOINT TEST (UHB) PROGRAM AS EFFORTS TO IMPROVE STUDENT LEARNING MOTIVATION}

\author{
I Suherman ${ }^{1 a}$ \\ 1 Program Studi Manajemen Pendidikan Islam, Fakultas Keguruan dan Ilmu Pendidikan, \\ Universitas Djuanda Bogor, Jl. Tol Ciawi No. 1 Kotak Pos 35 Ciawi Bogor 16720 \\ a Korespondensi: Irman Suherman, Email: irman.suherman@unida.ac.id \\ (Diterima: 14-09-2018; Ditelaah: 15-09-2018; Disetujui: 29-10-2018)
}

\begin{abstract}
This research aims to see the impact of the daily joint test (UHB) program on increasing students' learning motivation. The data used in this research were gathered from questionnaires and documents, and were analyzed by using simple linear regression to see the level of influence of the UHB program on students' learning motivation. The research focused on the students of SMA Negeri 4 in Bogor City. The learning motivation was illustrated by the students' attitudes in learning, readiness in learning, activeness in learning, and joy in learning, along with their concentration and material absorption. The coefficient of determination shows that the value of R Square 0.002 or $0.2 \%$, meaning the value of the UHB program as a form of impact on improving student learning motivation is very low. It can be said that $99.8 \%$ of students' learning motivation is influenced by other factors. The regression equation $\mathrm{Y}$ over $\mathrm{X}$ is $\hat{\mathrm{Y}}=71,280+0,028 \mathrm{X}$. With the regression equation, one can see that the UHB (X) Value variable with Student Learning Motivation (Y). When measured by the instrument developed in this study, a change in UHB score of one unit can be estimated to change Student Learning Motivation scores by 0.028 units in the same direction. This study shows, that the daily joint test (UHB) program, carried out by SMA Negeri 4 Bogor, in an effort to improve students' learning motivation, demonstrated unfavorable results. Giving scores as a result of a daily review program was not enough to motivate students in learning. The results of the data analysis showed a low influence of the daily testing on students' learning motivation. In further research on students' learning motivation, it is suggested to examine broader factors regarding the influence on students' motivation to increase learning not only limited to giving daily tests and grades. This further research is needed to provide complete information that can be used as a guide for teachers to improve learning.
\end{abstract}

Keywords: daily joint test program (UHB), students' learning motivation.

\section{ABSTRAK}

Penelitian ini bertujuan untuk melihat dampak dari program Ulangan Harian Bersama (UHB) terhadap peningkatan motivasi belajar siswa.Data yang digunakan dalam penelitian ini didapat dari angket dan dokumen, lalu dianalisis dengan menggunakan regresi linier sederhana untuk melihat tingkat pengaruh program UHB terhadap motivasi belajar siswa.Hasil penelitian menunjukkan motivasi belajar siswa SMA Negeri 4 Kota Bogor yang digambarkan dengan sikap siswa dalam belajar berupa kesiapan siswa dalam belajar, keaktifan siswa dalam belajar, rasa senang saat belajar, pemusatan perhatian, daya serap materi dan kesiapan siswa dalam mengerjakan tugassudah baik. Sedangkan koefisien 
determinasi menunjukkan nilai $\mathrm{R}$ Square 0,002 atau 0,2\%, bermakna niali UHB sebagai bentuk hasil dari program UHB tidak sama sekali memberikan dampak pada peningkatan motivasi belajar siswa dengan melihat sangat rendahnya pengaruh tersebu yaitu hanya $0,2 \%$ saja. Sehingga dapat dikatakan 99,8\% motivasi belajar siswa dipengaruhi oleh faktor lain.Sedangkan persamaan regresi $Y$ atas X, adalah $\hat{Y}=71,280+0,028 X$. Dengan persamaan regresi tersebut dapat diinterprestasikan bahwa jika variabel Nilai UHB (X) dengan Motivasi Belajar Siswa (Y) diukur dengan instrumen yang dikembangkan dalam penelitian ini, maka setiap perubahan skor UHB sebesar satu pada satuan dapat diestimasikan skor Motivasi Belajar Siswa akan berubah sebesar 0,028 satuan pada arah yang sama.Program Ulangan Harian Bersama (UHB) yang dilaksanakan oleh SMA Negeri 4 Kota Bogor sebagai upaya meningkatkan motivasi belajar siswa, pada penelitian ini menunjukkan hasil yang kurang baik dimana pemberian nilai sebagai hasil dari program ulangan harian tidak cukup untuk memotivasi siswa dalam pembelajaran.Hasil analisis data menunjukkan bahwa betapa rendahnya pengaruh nilai dalam ulangan harian tersebut terhadap motivasi belajar siswa yaitu hanya sebesar 0,02\%.Bagi peneliti selanjutnya tentang motivasi belajar siswa, disarankan untuk meneliti faktor yang lebih luas mengenai faktor-faktor yang mempengaruhi peningkatan motivasi belajar siswa tidak hanya terbatas pada pemberian ulangan harian dan nilai saja. Sehingga penelitian yang dihasilkan akan memberikan informasi yang lengkap dan dapat dijadikan pegangan bagi para guru guna memperbaiki pembelajran.

Kata kunci: motivasi belajar siswa, program ulangan harian bersama (UHB).

Suherman, I. (2018). Pengelolaan Program Ulangan Harian Bersama (UHB) sebagai Upaya Meningkatkan Motivasi Belajar Siswa. Tadbir Muwahhid, 2(2), 132-143.

\section{PENDAHULUAN}

Kegiatan belajar mengajar di sekolah merupakan inti dari pelaksanaan program pendidikan di sekolah. Ada interaksi antara guru dan siswa secara simultan didalamnya. Ada proses transfer ilmu yang terjadi saat kegiatan belajar mengajar berlangsung. Tidak hanya itu, ada juga proses transfer nilai (kepribadian, teladan) dari guru terhadap siswa.Pada akhir kegiatan belajar mengajar diharapkan siswa mampu memiliki kemampuan kognitif sebagai bentuk keberhasilan dari transfer ilmu. Kemudian adanya perubahan sikap (afektif) sebagai bentuk keberhasilan transfer nilai juga adanya perubahan keterampilan (psikomotorik) sebagai bentuk keberhasilan belajar lainnya.

Keberhasilan dari kegiatan belajar mengajar dari sisi kognitif biasanya diukur melalui tes.tes dalam kegiatan belajar mengajar merupakan suatu cara untuk mengevaluasi suatu kegiatan didalamnya ada bagian/item yang harus dikerjakan oleh siswa, kemudian hasil pekerjaan siswa tersebut diterjemahkan sebagai keberhasilan dari pencapaian siswa tersebut (Arifin, 1988). Sedangkan menurut Paul A. Bott (Rasyid \& Mansur, 2009) tes merupakan komponen paling utama yang harus dilakukan pada awal proses belajar mengajar sebagai bentuk pemetaan kemampuan siswa. Hal ini juga dilakukan untuk mengukur keberhasilan siswa dalam mencapai kompetensinya sebagai dampak dari kegiatan belajar mengajar (Sanjaya, 2010).

Melihat dari begitu pentingnya kegiatan tes dilakukan baik di awal maupun di akhirkegiatan belajar mengajar, maka kegiatan tes ini juga harus menunjukkan kualitas yang baik. Sebagaimana Arikunto (2009) menyampiakan ada lima ciri tes yang 
baik, yaitu: alat tes menunjukkan karakteristik validitas, reliabilitas, objektivitas, praktibilitas dan ekonomis.

Tes formatif adalah salah satu bentuk tes yang dapat dilakukan di akhir kegiatan belajar mengajar.Tes formatif adalah jenis evaluasi yang dilakukan dalam kegiatan belajar mengajar pada akhir setiap pembelajaran.Biasaya melalui tugastugas,ulangan singkat (kuis), ulangan harian atau tugas kegiatan praktif (Kunandar, 2011).Tes formatif juga merupakan tes yang diberikan kepada siswa setiap selesai materi per babnya pada mata pelajaran untuk mengetahui ketercapaian dari Tujuan Instruksional Khusus (TIK) (Depdiknas, 2008). Hal serupa juga disampaikan oleh Arikunto (2009)bahwa tujuan dari tes formatif adalah untuk mengukur tingkat ketercapaian penyampaian materi setiap bab nya dan juga untuk mengetahui tingkat penguasaan siswa terhadap materi yang telah diajarkan secara menyeluruh, dan atau dilakukan setelah selesai pokok bahasan tertentu (Imron, 2011).

Pelaksanaan tes formatif di sekolah saat ini dikenal dengan kegiatan ulangan harian dimana seorang guru melaksanakan ulangan harian pada setiap selesai penyampaian materi setiap babnya.Hal ini sering dilakukan karena ingin mengetahui keterserapan materi dari setiap babnya sebagai bentuk keberhasilan kegiatan pembelajaran yang dilakukan oleh guru.Namun guru pada prakteknya terkadang jarang melakukan evaluasi yang bersifat harian yaitu melalui ulangan harian.Padahal pemberian ulangan harian dan nilai secara berkala pada setiap akhir kegiatan belajar mengajar dapat meningkatkan motivasi belajar siswa di sekolah(Sadirman, 2011).

Dengan adanya sebuah pemahaman bahwa motivasi belajar siswa dapat ditingkatkan dengan ulangan harian, sedangkan pada prakteknya guru jarang sekali melakukan ulangan harian pada akhir setiap kegiatan belajar mengajar berlangsung. Maka ada sebuah terobosan baru yang dilakukan oleh Sekolah Menengah Atas Negeri 4 (SMA N 4) Kota Bogor yaitu membuat sebuah program Ulangah Harian Bersama (UHB). Program UHB ini bertujuan untuk melatih siswa agar selalu siap belajar hal ini menunjukkan motivasi belajar siswa yang baik.Sedangkan untuk guru program UHB ini diharapkan dapat memotivasi guru untuk lebih baik dalam mengajar dan menyiapkan bahan untuk evaluasi setiap akhir pembelajaran dengan memperhatikan kesesuaian soal dengan materi yang diajarkan.

Hasil dari program UHB adalah berupa nilai (angka) yang bersifat kognitif. Nilai ini dimanfaatkan untuk mengetahui perkembangan anak secara berkala, sedangkan datanya digunakan sebagai bahan kajian tim pengembangan dan penjamin mutu untuk dievaluasi dan dilaporkan kepada orang tua siswa.

\section{MATERI DAN METODE}

Jenis penelitian ini adalah penelitian deskriptif kuantitatif. Penelitian yang menguraikan gejala, fenomena dan fakta yang diteliti dengan cara memberikan gambaran yang menyeluruh dari setiap variabel penelitian (Musfiqon, 2012). Penelitian ini dilaksanakan pada tahun pelajaran 2012-2013 di Sekolah Menengah Atas Negeri 4 (SMA N 4) Kota Bogor.

Populasi adalah seluruh subjek yang dilibatkan dalam penelitian (Arikunto, 2010). Pada penelitian ini yang menjadi populasi adalah seluruh siswa kela XI program IPA dan IPS SMA N 4 Kota Bogor dengan jumlah 364 siswa yang terdiri dari 
280 siswa kelas XI IPA dan 84 siswa kelas XI IPS. Sedangkan sampel adalah bagian yang mewakili dari populasi (Riduwan, 2009). Untuk menentukan jumlah sampel agar mendapatkan sampel yang representatif, peneliti menggunakan tabel penentuan sampel dari populasi yang dikembangkan oleh Isaac dan Michael.

Tabel 1 Penentuan jumlah sampel dari populasi tertentu dengan taraf kesalahan 1\%, 5\% dan 10\%.

\begin{tabular}{cccc}
\hline \multirow{2}{*}{$\mathrm{N}$} & \multicolumn{3}{c}{$\mathrm{S}$} \\
\cline { 2 - 4 } & $1 \%$ & $5 \%$ & $10 \%$ \\
\hline 300 & 207 & 161 & 143 \\
320 & 216 & 167 & 147 \\
340 & 225 & 172 & 151 \\
360 & 234 & 177 & 155 \\
380 & 242 & 182 & 158 \\
400 & 250 & 186 & 162 \\
\hline
\end{tabular}

Sumber: Isaac \& Michael (Sugiyono, 2015)

Berdasarkan tabel 1, maka untuk tingkat kesalah 5\% dari jumlah populasi 364 siswa didapat jumlah sampel sebanyak 177 siswa.

Teknik sampling yang digunakan dalam penelitian ini adalah random sampling (probability sampling) yaitu cara menentukan atau mengambil sampel secara acak tanpa memperhatikan kriteria atau tanpa pandang bulu. Sehingga semua siswa yang menjadi populasi memiliki kesempatan yang sama untuk dipilih menjadi anggota sampel (Margono, 2010).

Data yang dikumpulkan berupa data yang berhubungan dengan program Ulangan Harian Bersama (UHB) dan motivasi belajar siswa baik yang bersifat angga maupun yang bersifat deskriptif dalam dokumen.Data tersebut didapatkan melalui interview (wawancara), penyebaran angket (kuesioner) dan telaah dokumen.

\section{a. Interview (wawancara)}

Wawancara digunakan sebagai teknik pengumpulan data apabila penelitian ingin melakukan studi pendahuluan sebagai sarana untuk menentukan permasalah yang harus diteliti.Selin itu juga apabila peneliti ingin mengtahui hal-hal yang terkait dengan topik penelitian secara mendalam (Sugiyono, 2015).

b. Angket (kuesioner)

Angket (kuesioner) adalah alat pengumpulan informasi dengan cara penyampaian sejumlah pertanyaan tertulis dan juga jawabannya pun diberikan secara tertulis oleh responden (Margono, 2009). Pengukuran variabel melalui angket ini adalah menggunakan skala likert. Kemudian angket ini sebelum digunakan diuji validitas dan reliabilitasnya terlebih dahulu untuk mengetahui tingkat keshahihan dan kelayakannya atau mengukur apa yang tercantum pada tujuan penelitian secara benar (Sandjaja \& Hariyanto, 2012).

c. Dokumen

Dokumen adalah catatan yang tertulis atau tercetak dari sebuah kegiatan yang digunakan sebagai bukti dan atau keterangan (Depdiknas, 2008). Pada penelitian ini dokumen yang dimaksud adalah arsip nilai dari program Ulangan Harian Bersama (UHB), dokumentasi tentang data sekolah, data siswa, kurikulum dan data lain yang terkait dengan program UHB.

Data yang didapatkan dianalisis dengan teknik regresi sederhana. Yaitu untuk meramalkan varibel terikat (Y) apabila variabel bebas (X) diketahui. Regresi sederhana ini dapat dianalisis karena didasari oleh hubungan fungsional antara variabel bebas $(\mathrm{X})$ terhadap variabel terikat (Y) (Riduwan, 2011). Adapun persamaan rumus regresi sederhana:

$\hat{\mathrm{Y}}=\mathrm{a}+\mathrm{bX}$

Keterangan: $\hat{Y}=$ subjek variabel terikat yang diproyeksikan; $\mathrm{a}=$ nilai konstanta harya $\mathrm{Y}$ jika $\mathrm{X}=0$; 
$\mathrm{b}=$ nilai arah sebagai penentu ramalan (prediksi) yang menunjukkan nilai peningkatan $(+)$ atau penurunan $(-)$ variabel $\mathrm{Y}$; $\mathrm{X}=$ variabel bebas yang mempunyai nilai tertentu untuk diprediksikan.

\section{HASIL DAN PEMBAHASAN}

\section{Pengelolaan Program Ulangan Harian Bersama}

Pengelolaan program Ulangan Harian Bersama (UHB) yang dilaksanakan oleh SMA Negeri 4 Kota Bogor dipimpin langsung oleh kepala sekolah dengan pelaksana teknisnya di bawah wakil kepala sekolah bidang kurikulum.Secara struktur organisasi sekolah kepala sekolah ini dibantu oleh empat orang wakil kepala sekolah yang memiliki tugas masing-masing sesuai dengan bidangnya.Yaitu wakil kepala sekolah bidang kurikulum, wakil kepala sekolah bidang kesiswaan, wakil kepala sekolah bidang sarana dan prasarana dan wakil kepala sekolah bidang hubungan masyarakat.

Masing-masing wakil kepala sekolah ini memiliki tugas dan fungsnya tersendiri. Kaitannya dengan program Ulangan Harian Bersama (UHB) di SMA Negeri 4 Kota Bogor, ini secara langsung dikelola dan dilaksanakan oleh wakil kepala sekolah bidang kurikulum. Adapun tugas wakil kepala sekolah bidang kurikulum secara khusus sebagai berikut:

1) Membuat program urusan kurikulum yang berorientasi pada visi, misi dan strategi yang sudah ditetapkan dalam arti bahwa administrasi sekolah menunjang tercapaianya tujuan pendidikan;

2) Menyusun perangkat pembelajaran;

3) Menyusun pembagian tugas guru;

4) Menyusun jadwal pelajaran;
5) Menyususn jadwal evaluasi belajar (UHB, UTS, UAS, UKK);

6) Menyusun pelaksanaan Ujian Akhir Sekolah dan Ujian Nasional (UN);

7) Menerapkan kriteria persyaratan naik kelas/tidak naik kelas serta penjurusan;

8) Menetapkan jadwal penerimaan buku laporan pendidikan dan penerimaan ijazah;

9) Menyiapkan buku kemajuan kelas;

10)Menyusun laporan pelaksanaan pelajaran;

11)Mengkoordinasikan penyusunan dan revisi kurikulum SMA Negeri 4 Kota Bogor;

12)Merancang dan menfasilitasi format kelengkapan administrasi pembelajaran;

13)Merencanakan dan membuat program kegiatan klinik akademik dan pengayaan sesuai dengan masing-masing mata pelajaran yang di Ujian Nasional-kan;

14)Memberikan pelayanan klinik akademik para siswa sesuai dengan jadwal yang sudang dibuat dan disepakati di luar jam pelajaran intra;

15)Berkoodinasi dengan seluruh wakil kepala sekolah;

16)Melaksanakan lapoaran hasil dan presentase target kelulusan secara berkala kepada kepala sekolah;

17)Melaksanakan pelaporan pelaksanaan program secara berkala kepada kepala sekolah.

Melihat tugas dan fungsi wakil kepala sekolah bidang kurikulum, maka pengelolaan program Ulangan Harian Bersama (UHB) di SMA Negeri 4 Kota Bogor langsung dibawah koordinasi dan arahan wakil kepala sekolah bidang kurikulum tersebut. 


\section{Perencanaan}

Perencanaan merupakan sebuah kegiatan yang dilakukan secara sadar, sistematis dan rasional sebagai upaya menwujudkan tujuan dengan memanfaatkan semua sumber daya yang ada.Sehingga perencanaan disusun berdasarkan data, fakta-fakta dan informasi yang didapat pada masa ini.Dengan kata lain Perencanaan adalah kegiatan yang berhubungan dengan masa depan yang diperoleh dari data, fakta dan informasi masa lalu (Coombs, 1982). Selain itu, Usman dalam (Gunawan, 2017) menyatakan bahwa tujuan dibuatnya perencanaan adalah untuk menentukan standar pengawasan dari pelaksanaan suatu program dengan mengacu pada target, sasaran dan hal-hal yang telah direncanakannya, diantarannya penetapan waktu, sumber daya manusia (siapa yang akan terlibat), penganggaran yang berorientasi pada tujuan.

Berkaitan dengan program Ulangan Harian Bersama (UHB) di SMA Negeri 4 Kota Bogor, kepala sekolah sebagai pimpinan tertingginya. Menyusun dan membuat perencanaan terkait dengan program tersebut.Program UHB dilaksanakan pada setiap semesternya sebanyak dua kali, semua guru terlibat dalam kegiatan ini terutama guru mata pelajaran. Pelaksanaan program UHB sama seperti ulangan pada umumnya yaitu seperti Ulangan Tengah Semester (UTS) atau Ulangan Akhir Semester (UAS) dengan bentuk tes tertulis yang hasilnya berupa nilai. Untuk mempermudah pelaksanaan program tersebut maka dibentuklah sebuah panitia sebagai personalia yang bertanggungjawab dalam penyediaan soal dan lembar jawaban, administrasi, pembuatan jadwal, pembagian kelas dan hal-hal yang mendukung dalam pelaksanaannya.Program UHB ini bertujuan untuk melatih siswa agar selalu siap ujian, sehingga siswa memiliki motivasi belajar yang tinggi.

\section{Pelaksanaan}

Program Ulangan Harian Bersama (UHB) di SMA Negeri 4 Kota Bogor dilaksanakan sesuai dengan jadwal yang telah ditetapkan oleh panitia. Sebagaimana kegiatan ujian yang lain, maka UHB ini juga dalam pelaksanaannya diawasi oleh pengawas yang telah ditentukan sebelumnya.Pada semester ganjil pelaksanaan program Ulangan Harian Bersam (UHB) dilaksanakan pada bulan September dan November sedangkan pada semester genap dilaksanakan pada bulan Februari dan April.

Mata pelajaran yang diujiankan pada program UHB adalah semua mata pelajaran yang ada dalam kurikulum.Mata pelajaran yang diujikan sesuai dengan jadwal yang telah ditetapkan sekitar dua sampai tiga mata pelajaran saja.

\section{Evaluasi}

Evaluasi adalah kegiatan yang mengukur ketercapaian suatu program dengan melihat target yang telah ditetapkan dalam perencanaan dengan hasil yang didapat saat akhir pelaksanaanya. Sebagaimana program Ulangan Harian Bersama (UHB) merupakan kegiatan ujian yang sama halnya dengan kegiatan ujian lainnya. Maka yang menjadi target dari program tersebut adalah berupa nilai yang di atas standar minimum.Ratarata standar Kriteria Ketuntasan Minum (KKM) yang ditetapkan adalah 70.0 dengan tingkatan nilai baik "B".Pada penelitian ini data yang digunakan adalah data program UHB yang dilaksanakan pada semester ganjil yaitu pelaksanaan UHB pada bulan September dan November. Adapun nilai rata-rata yang diperoleh dapat dilihat pada tabel 2. Adapun untuk melihat jumlah siswa 
yang mendapatkan nilai di atas KKM dan di bawah KKN dapat dilihat pada tabel 3.

Tabel 2 Nilai rata-rata pada setiap mata pelajaran

\begin{tabular}{llc}
\hline No. & Nama Mata Pelajaran & $\begin{array}{c}\text { Nilai Rata- } \\
\text { rata }\end{array}$ \\
\hline 1. & $\begin{array}{l}\text { Pendidikan Agama Islam } \\
\text { (PAI) }\end{array}$ & 77,92 \\
2. & PKN & 72,43 \\
3. & Bahasa Indonesia (IND) & 59,13 \\
4. & Bahasa Inggris (ING) & 58,82 \\
5. & TIK & 81,85 \\
6. & Bahasa Sunda (SUN) & 80,30 \\
7. & PLH & 81,97 \\
\hline
\end{tabular}

Data pada tabel 2 secara umum nilai ratarata pada setiap mata pelajaran menunjukkan bahwa terdapat dua mata pelajaran yang tidak memenuhi standar KKM yaitu mata pelajaran Bahasa Indonesia dan Bahasa Inggris.Hal ini juga diperkuat dengan perolehan data tentang jumlah siswa dengan standar KKM-nya pada setiap mata pelajaran pada tabel 3. Data menunjukkan bahwa pada pada pelajaran Bahasa Indonesia hanya 10 orang yang memnuhi standa KKM atau hanya 6\% saja dari jumlah siswa yang menjadi sampel. Selain itu juga pada mata pelajaran Bahasa Inggris hanya 26 orang yang telah memenuhi standar KKM atau sebesar 15\%. Sedangkan pada mata pelajaran yang lain sudah menunjukkan hasil yang baik.

Tabel 3 Jumlah siswa dengan standar KKM

\begin{tabular}{clccccccc}
\hline No. & Uraian & PAI & PKN & IND & ING & TIK & SUN & PLH \\
\hline 1. & Nilai $\geq$ KKM & 151 & 126 & 10 & 26 & 161 & 165 & 165 \\
2. & Nilai $<$ KKM & 26 & 51 & 167 & 151 & 16 & 12 & 12 \\
\hline
\end{tabular}

\section{Motivasi Belajar Siswa}

Sebagaimana menurut Sadirman (2011) pemberian angka berupa simbol nilai dan ulangan pada setiap mata pelajaran dapat meningkatkan motivasi belajar siswa.Dengan begitu diharapkan akan muncul keinginan (initiate) dari masingmasing siswa sebagai bentuk motivasi dalam dirinya sendiri untuk meningkatkan kualitas belajaranya (Asnawi, 2002)

Indikator motivasi belajar siswa pada penelitian ini ditunjukkan dengan kesiapan siswa dalam belajar, keaktifan siswa, rasa senang saat belajar, pemusatan perhatian, dasar serap materi meningkat dan kesiapan mengerjakan tugas pada setiap mata pelajaran.

Pada tahap analisis data motivasi belajar siswa, data dari hasil pengolahan angket dianalisis menggunakan pendekatan Weight
Means Score (WMS) untuk mengetahui kecenderungan dimensi variabel. Nilai ratarata yang diperoleh kemudian dikonsultasikan dengan tabel konsultasi WMS sebagaimana dilihat pada tabel 4 .

Tabel 4 Daftar konsultasi hasil perhitungan WMS

\begin{tabular}{cl}
\hline Rating Nilai & \multicolumn{1}{c}{ Kriteria } \\
\hline $4,01-5,00$ & Sangat Baik \\
$3,01-4,00$ & Baik \\
$2,01-3,00$ & Cukup \\
$1,01-2,00$ & Kurang \\
$0,01-1,00$ & Sangat Kurang \\
\hline
\end{tabular}

Sumber: Diadaptasi dari Akdon dan Hadi (2005, hal. 39)

Adapun data kecenderungan variabel motivasi belajar siswa yang didapatkan dari penyebaran kuesioner yang dilakukan setelah pelaksanaan program Ulangan Harian Bersama (UHB) yaitu pada bulan Januari 2013 dapat dilihat pada tabel 5. 
Tabel 5 Nilai Weight Means Score(WMS) motivasi belajar siswa

\begin{tabular}{|c|c|c|c|c|c|c|c|c|c|c|c|c|c|c|c|}
\hline \multirow{3}{*}{$\begin{array}{c}\text { Indikato } \\
\mathrm{r}\end{array}$} & \multirow{3}{*}{$\begin{array}{c}\text { No } \\
\text { Item }\end{array}$} & \multicolumn{10}{|c|}{ Skala Penilaian } & \multirow{2}{*}{\multicolumn{2}{|c|}{ Jumlah }} & \multirow{3}{*}{$\begin{array}{c}\text { Rata } \\
\text {-rata } \\
X / F\end{array}$} & \multirow{3}{*}{ Kriteria } \\
\hline & & \multicolumn{2}{|c|}{5} & \multicolumn{2}{|c|}{4} & \multicolumn{2}{|c|}{3} & \multicolumn{2}{|c|}{2} & \multicolumn{2}{|c|}{1} & & & & \\
\hline & & $\mathrm{F}$ & $\mathrm{X}$ & $\mathrm{F}$ & $\mathrm{X}$ & $\mathrm{F}$ & $\mathrm{X}$ & $\mathrm{F}$ & $\mathrm{X}$ & $\mathrm{F}$ & $\mathrm{X}$ & $\mathrm{F}$ & $\mathrm{X}$ & & \\
\hline \multirow{6}{*}{ 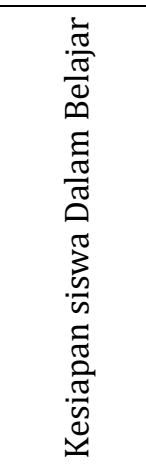 } & 1 & 29 & $\begin{array}{c}14 \\
5\end{array}$ & 10 & 40 & 98 & 294 & $\begin{array}{l}3 \\
4\end{array}$ & 68 & 6 & 6 & $\begin{array}{c}17 \\
7\end{array}$ & $\begin{array}{c}55 \\
3\end{array}$ & 3.12 & Baik \\
\hline & 2 & 15 & 75 & 16 & 64 & 99 & 297 & $\begin{array}{l}3 \\
8\end{array}$ & 76 & 9 & 9 & $\begin{array}{c}17 \\
7\end{array}$ & $\begin{array}{c}52 \\
1\end{array}$ & 2.94 & Kurang \\
\hline & 3 & $\begin{array}{c}11 \\
8\end{array}$ & $\begin{array}{c}59 \\
0\end{array}$ & 10 & 40 & 29 & 87 & $\begin{array}{l}1 \\
2\end{array}$ & 24 & 8 & 8 & $\begin{array}{c}17 \\
7\end{array}$ & $\begin{array}{c}74 \\
9\end{array}$ & 4.23 & $\begin{array}{c}\text { Sangat } \\
\text { Baik }\end{array}$ \\
\hline & 4 & 38 & $\begin{array}{c}19 \\
0\end{array}$ & 18 & 72 & 68 & 204 & $\begin{array}{l}3 \\
5\end{array}$ & 70 & $\begin{array}{l}1 \\
8\end{array}$ & 18 & $\begin{array}{c}17 \\
7\end{array}$ & $\begin{array}{c}55 \\
4\end{array}$ & 3.13 & Baik \\
\hline & 5 & $\begin{array}{c}12 \\
2 \\
\end{array}$ & $\begin{array}{c}61 \\
0 \\
\end{array}$ & 29 & $\begin{array}{c}11 \\
6 \\
\end{array}$ & 15 & 45 & 9 & 18 & 1 & 1 & $\begin{array}{c}17 \\
6 \\
\end{array}$ & $\begin{array}{c}79 \\
0 \\
\end{array}$ & 4.49 & $\begin{array}{c}\text { Sangat } \\
\text { Baik }\end{array}$ \\
\hline & \multicolumn{13}{|c|}{ Total rata-rata Indikator } & 3.58 & Baik \\
\hline \multirow{5}{*}{ 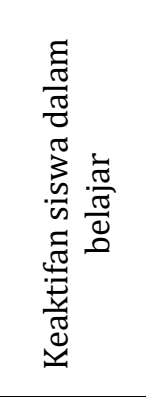 } & 6 & 10 & 50 & 14 & 56 & $\begin{array}{c}10 \\
5\end{array}$ & 315 & $\begin{array}{l}4 \\
1\end{array}$ & 82 & 7 & 7 & $\begin{array}{c}17 \\
7\end{array}$ & $\begin{array}{c}51 \\
0\end{array}$ & 2.88 & Kurang \\
\hline & 7 & 16 & 80 & 12 & 48 & 86 & 258 & $\begin{array}{l}5 \\
4\end{array}$ & $\begin{array}{c}10 \\
8\end{array}$ & 9 & 9 & $\begin{array}{c}17 \\
7\end{array}$ & $\begin{array}{c}50 \\
3\end{array}$ & 2.84 & Kurang \\
\hline & 8 & 57 & $\begin{array}{c}28 \\
5\end{array}$ & 49 & $\begin{array}{c}19 \\
6\end{array}$ & 58 & 174 & $\begin{array}{l}1 \\
1\end{array}$ & 22 & 2 & 2 & $\begin{array}{c}17 \\
7\end{array}$ & $\begin{array}{c}67 \\
9\end{array}$ & 3.84 & Baik \\
\hline & 9 & 40 & $\begin{array}{c}20 \\
0\end{array}$ & 26 & $\begin{array}{c}10 \\
4\end{array}$ & 87 & 261 & $\begin{array}{l}1 \\
9\end{array}$ & 38 & 5 & 5 & $\begin{array}{c}17 \\
7\end{array}$ & $\begin{array}{c}60 \\
8\end{array}$ & 3.44 & Baik \\
\hline & \multicolumn{13}{|c|}{ Total rata-rata Indikator } & 3.25 & Baik \\
\hline \multirow{2}{*}{ 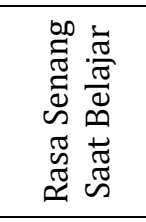 } & 10 & 112 & $\begin{array}{c}56 \\
0\end{array}$ & 19 & 76 & 41 & 123 & 3 & 6 & 2 & 2 & $\begin{array}{c}17 \\
7\end{array}$ & $\begin{array}{c}76 \\
7\end{array}$ & 4.33 & $\begin{array}{c}\text { Sangat } \\
\text { Baik }\end{array}$ \\
\hline & \multicolumn{13}{|c|}{ Total rata-rata Indikator } & 4.33 & $\begin{array}{c}\text { Sangat } \\
\text { Baik }\end{array}$ \\
\hline \multirow{3}{*}{ 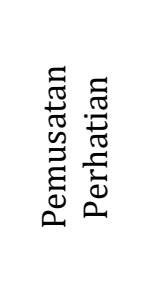 } & 11 & 95 & $\begin{array}{c}47 \\
5\end{array}$ & 46 & $\begin{array}{c}18 \\
4\end{array}$ & 34 & 102 & 2 & 4 & 0 & 0 & $\begin{array}{c}17 \\
7\end{array}$ & $\begin{array}{c}76 \\
5\end{array}$ & 4.32 & $\begin{array}{c}\text { Sangat } \\
\text { Baik }\end{array}$ \\
\hline & 12 & 109 & $\begin{array}{c}54 \\
5 \\
\end{array}$ & 30 & $\begin{array}{c}12 \\
0 \\
\end{array}$ & 29 & 87 & 7 & 14 & 2 & 2 & $\begin{array}{c}17 \\
7 \\
\end{array}$ & $\begin{array}{c}76 \\
8 \\
\end{array}$ & 4.34 & $\begin{array}{c}\text { Sangat } \\
\text { Baik }\end{array}$ \\
\hline & \multicolumn{13}{|c|}{ Total rata-rata Indikator } & 4.33 & $\begin{array}{c}\text { Sangat } \\
\text { Baik }\end{array}$ \\
\hline
\end{tabular}

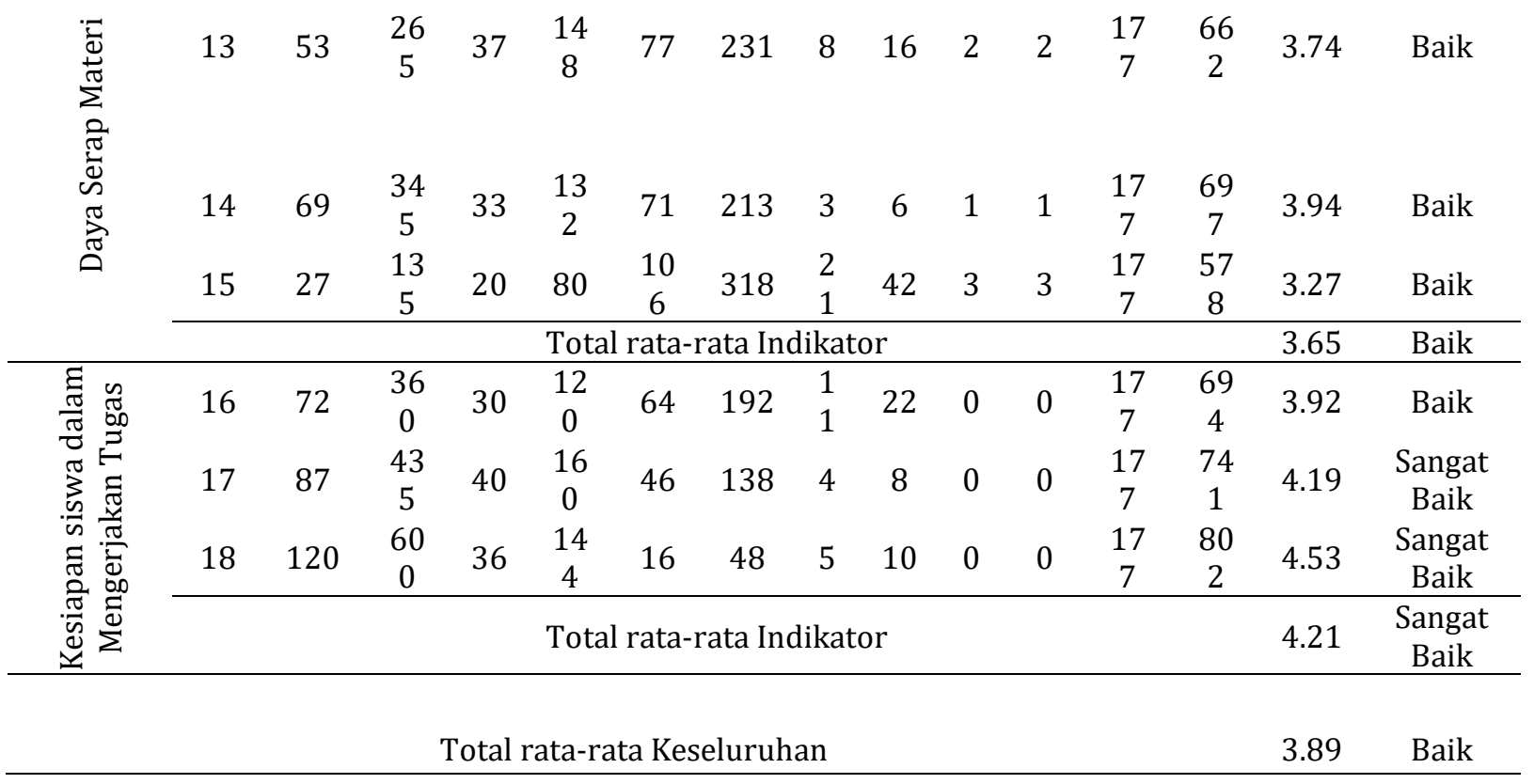




\section{Dampak Nilai Ulangan Harian Pada Motivasi Belajar Siswa}

Pada penelitian ini program Ulangan Harian Bersama (UHB) merupakan variabel dependen sedangkan motivasi belajar siswa merupakan variabel independennya.Analisis koefisien korelasi dihitung dengan bantuan SPSS 20.0 for Windows.Nilai korelasi variabel Nilai Ulangan Harian Bersama (X) terhadap Motivasi Belajar Siswa (Y) dilihat pada nilai korelasi Pearson Product Moment.Hasil perhitungan dapat dilihat pada tabel 6 .

Tabel 6 Korelasi variabel X dan Y

\begin{tabular}{|c|c|c|c|}
\hline \multicolumn{4}{|c|}{ Correlations } \\
\hline & & Nilai UHB & $\begin{array}{c}\text { Motivasi Belajar } \\
\text { Siswa }\end{array}$ \\
\hline \multirow{3}{*}{ Nilai UHB } & Pearson Correlation & 1 & ,046 \\
\hline & Sig. (2-tailed) & & ,544 \\
\hline & $\mathrm{N}$ & 177 & 177 \\
\hline \multirow{3}{*}{ Motivasi Belajar Siswa } & Pearson Correlation & ,046 & 1 \\
\hline & Sig. (2-tailed) &, 544 & \\
\hline & $\mathrm{N}$ & 177 & 177 \\
\hline
\end{tabular}

Berdasarkan hasil perhitungan pada tabel 6 diatas, nilai korelasi yang diperoleh untuk Xdengan $Y$ sebesar 0,046 jika dibandingkan dengan nilai $r_{\text {tabelsebesar }}$ 0,145 maka nilai koefisien korelasi $<r_{\text {tabel, }}$ maka tidak ada korelasi antara Nilai UHB dengan motivasi belajar siswa. Sedangkan Uji signifikasi untuk Xdengan $\mathrm{Y}$ diperoleh nilai signifikan 0,544>0.05, yang artinya tidak terdapat hubungan yang signifikan. Maka kesimpulan yang dapat diambil adalah tidak terdapat hubungan signifikan antara Nilai Ulangan Harian Bersama (UHB) terhadap Motivasi Belajar Siswa.

Untuk melihat lebih lanjut, maka dilakukan analisis koefisien determinasi dan uji regresi sebagai berikut:

Tabel 7 Koefisien determinasi

\begin{tabular}{ccccc}
\hline \multicolumn{4}{c}{ Model Summary } \\
\hline Model & $\mathrm{R}$ & $\mathrm{R}$ & $\begin{array}{c}\text { Adjusted } \\
\text { Square }\end{array}$ & $\begin{array}{c}\text { R Square } \\
\text { Error of } \\
\text { the } \\
\text { Estimate }\end{array}$ \\
\hline 1 &, $046^{\mathrm{a}}$ &, 002 &,- 004 & 5,12972 \\
\hline
\end{tabular}

a. Predictors: (Constant), Motivasi Belajar Siswa
Pada tabel 7 koefisien determinasi menunjukkan nilai $\mathrm{R}$ Square 0,002 atau $0,2 \%$, bermakna niali UHB sebagai bentuk hasil dari program UHB tidak sama sekali memberikan dampak pada peningkatan motivasi belajar siswa dengan melihat sangat rendahnya pengaruh tersebu yaitu hanya $0,2 \%$ saja. Sehingga dapat dikatakan 99,8\% motivasi belajar siswa dipengaruhi oleh faktor lain.

Rumus persamaan regresi antara variabel Xdengan $\mathrm{Y}$ adalah $\hat{Y}=a+$ $b X$,perhitungan dengan bantuan SPSS 20.0for Windows diperoleh hasil seperti pada tabel 8.

Berdasarkan tabel 8, persamaan regresi $Y$ atas $\mathrm{X}$, adalah $\hat{\mathrm{Y}}=71,280+0,028 \mathrm{X}$. Dengan persamaan regresi tersebut dapat diinterprestasikan bahwa jika variabel Nilai $\mathrm{UHB}(\mathrm{X})$ dengan Motivasi Belajar Siswa (Y) diukur dengan instrumen yang dikembangkan dalam penelitian ini, maka setiap perubahan skor UHBsebesar satu pada satuan dapat diestimasikan skor Motivasi Belajar Siswaakan berubah sebesar 0,028 satuan pada arah yang sama. 
Tabel 8 Persamaan regresi

\begin{tabular}{|c|c|c|c|c|c|c|}
\hline \multicolumn{7}{|c|}{ Coefficients $^{\mathrm{a}}$} \\
\hline \multirow[t]{2}{*}{ Model } & & \multicolumn{2}{|c|}{$\begin{array}{c}\text { Unstandardized } \\
\text { Coefficients } \\
\end{array}$} & \multirow{2}{*}{$\begin{array}{c}\text { Standardized } \\
\text { Coefficients }\end{array}$} & \multirow[t]{2}{*}{$\mathrm{t}$} & \multirow[t]{2}{*}{ Sig. } \\
\hline & & $\mathrm{B}$ & Std. Error & & & \\
\hline & (Constant) & 71,280 & 3,187 & & 22,368 & ,000 \\
\hline 1 & $\begin{array}{l}\text { Motivasi Belajar } \\
\text { Siswa }\end{array}$ & ,028 & ,047 & ,046 & 608 &, 544 \\
\hline
\end{tabular}

Kriteria pengujian persamaan regresi adalah diterima jika probabilitas lebih kecil dari alpha $=0,05$. Berdasarkan tabel di atas nilai probabilitas sebagaimana ditunjukkan pada kolom Sig/Significance adalah 0.544 sehingga nilai probabilitas $>0,05$. Dapat disimpulkan koefisien regresi tidak signifikan, atau Nilai Ulangan Harian Bersama (X) tidak memiliki pengaruh terhadap peningkatan Motivasi Belajar Siswa (Y).

\section{Pembahasan}

Motivasi belajar siswa atau dorongan yang timbul dari seorang siswa untuk melakukan aktivitas belajar dengan sungguh-sungguh dan baik adalah harapan dari semua guru yang ada di sekolah.Dimana setiap siswa dengan penuh semangat dan antusias mengikuti pembelajaran yang dilaksankan di dalam maupun di luar sekolah. Oleh karena itu, terkadang pihak sekolah melakukan berbagai cara untuk meningkatkan motivasi tersebut.

Motivasi belajar siswa pada penelitian ini yang ditunjukkan oleh sikap siswa dalam belajar berupa kesiapan siswa dalam belajar, keaktifan siswa dalam belajar, rasa senang saat belajar, pemusatan perhatian, daya serap materi dan kesiapan siswa dalam mengerjakan tugas menggambarkan motivasi belajar siswa yang baik. Dimana nilai rata-rata sebesar 3,89 jika dikonsultasikan dengan kriteria capaian berada pada posisi baik. Artinya secara keseluruhan rata-rata motivasi belajar siswa di SMA Negeri 4 Kota Bogor sudah baik.

Dalam hal upaya meningkatkan motivasi belajar siswa Sadirman A.M(2011) mengemukakan ada lima cara yang bisa dilakukan oleh guru atau sekolah untuk meningkatkan motivasi siswa dalam kegiatan belajar yaitu pemberian nilai angka, pemberian hadiah, sistem kompetisi dalam pembelajaran, menumbuhkan egoinvolvement beruapa menumbuhkan kesadaranakan pentingnya mengerjakan tugas sebagai tantangan sebagai bentuk mempertahankan harga diri dan memberikan ulangan.

Namun jika dikaitkan program Ulangan Harian Bersama (UHB) yang dilaksanakan oleh SMA Negeri 4 Kota Bogor sebagai upaya meningkatkan motivasi belajar siswa, pada penelitian ini menunjukkanhasil yang kurang baik dimana bahwa pemberian nilai sebagai hasil dari program ulangan harian tidak cukup untuk memotivasi siswa dalam pembelajaran. Dimana hasil analisis data menunjukkan bahwa betapa rendahnya pengaruh nilai dalam ulangan harian tersebut terhadap motivasi belajar siswa yaitu hanya sebesar $0,02 \%$ saja dampaknya. Hal ini berarti motivasi belajar siswa lebih besar dipengaruhi oleh faktor lain. Jika merujuk pada pendapat Sadirman A.M di atas, bisa saja faktor yang dapat 
memberikan dampak besar terhadap peningkatan motivasi belajar siswa adalah sistem kompetisi dalam pembelajaran yang dilakukan oleh guru, juga metode guru dalam minumbuhkan ego-involvement siswa dan pemberian hadiah. Jika dilihat dari faktor-faktor tersebut, semuanya terdapat pada bagaimana guru melaksanakan sistem pembelajarannya.

Hal tersebut pula sesuai dengan pendapat De Decce dan Grawford (Islamuddin, 2012) menyampaikan bahwa empat fungsi guru yang hubungannya dengan peningkatan motivasi belajar siswa adalah menggairahkan siswa dalam belajar dengan memberikan kebebasan kepada siswa dalam mengeksplorasi potensinya, memberikan harapan yang realistis, memberikan insentif (hadiah) dan mengarahkan perilaku siswa terutama dalam hal-hal yang berkaitan dengan pembelajaran.

\section{KESIMPULAN DAN IMPLIKASI}

\section{Kesimpulan}

Berdasarkan hasil penelitian variabel motivasi belajar siswa di SMA Negeri 4 Kota Bogor sudah baik.Namun jika dikaitkan dengan program Ulangan Harian Bersama (UHB) yang dilaksanakan oleh SMA Negeri 4 Kota Bogor menunjukkan hasil yang kurang baik yaitu tidak memberikan dampak terhadap peningkatan motivasi belajar siswa.Sehingga dapat disimpulkan bahwa program Ulangan Harian Bersama (UHB) yang dilaksanakan oleh SMA Negeri 4 Kota Bogor jika dikaitkan dengan upaya peningkatan motivasi belajar siswanya tidak memberikan dampak yang tinggi.

\section{Implikasi}

Bagi para peneliti tentang motivasi belajar siswa selanjutnya, disarankan untuk meneliti faktor yang lebih luas mengenai faktor-faktor yang mempengaruhi peningkatan motivasi belajar siswa. Sehingga penelitian yang dihasilkan akan memberikan informasi yang lengkap dan dapat dijadikan pengagan bagi para stakeholder guna memperbaiki pendidikan. Khususnya meningkatkan kegiatan pembelajaran yang dilaksanakan oleh para guru di sekolah.

\section{DAFTAR PUSTAKA}

A.M, Sadirman. (2011). Interaksi dan Motivasi Belajar Mengajar. Jakarta: RajaGrafindo Persada.

Akdon, \& Hadi, S. (2005). Aplikasi Statistika dan Metode Penelitian Untuk Administrasi \& Manajemen. Bandung: Dewa Ruchi.

Arifin, Z. (1988). Evaluasi Intruksional. Bandung: Remaja Rosdakarya.

Arikunto, S. (2009). Dasar-dasar Evaluasi Pendidikan. Jakarta: Bumi Aksara.

Arikunto, S. (2010). Prosedur Penelitian. Jakarta: Rineka Cipta.

Asnawi, S. (2002). Teori Motivasi dalam Pendekatan Psikologi, Industri dan Organisasi. Jakarta: Syuda Press.

Depdiknas. (2008). KBBI. Jakarta: Gramedia Pustaka Utama.

Imron, A. (2011). Manajemen Peserta Didik Berbasis Sekolah. Jakarta: Bumi Aksara.

Islamuddin, H. (2012). Psikologi Pendidikan. Yogyakarta: Pustaka Pelajar.

Kunandar. (2011). Guru Profesionalisme. Jakarta: Rajawali Pres.

Margono. (2009). Metodologi Penelitian Pendidikan. Jakarta: Rineka Cipta.

Margono. (2010). Metode Penelitian Pendidikan. Bandung: Alfabeta. 
Musfiqon, H. (2012). Panduan Lengkap Metodologi Penelitian Pendidikan. Jakarta: Prestasi Pustaka.

Rasyid, H., \& Mansur. (2009). Penilaian Hasil Belajar. Bandung: Wacana Prima.

Riduwan. (2009). Metode dan Teknik Menyusun Proposal Penelitian. Bandung: Alfabeta.

Riduwan. (2011). Pengantar Statistika. Bandung: Alfabeta.
Sadirman, A. M. (2011). Interaksi dan Motivasi Belajar Mengajar. Jakarta: RajaGrafindo.

Sandjaja, B., \& Hariyanto, A. (2012). Panduan Penelitian. Bandung: Alfabeta.

Sanjaya, W. (2010). Perencanaan dan Desain Sistem Pembelajaran. Jakarta: Kencana.

Sugiyono. (2015). Metode Penelitian Pendidikan (Pendekatan Kuantitatif, Kualitatif dan R\&D). Bandung: Alfabeta. 